\title{
Competent Authority Applicant
}

National Cancer Institute

\section{Source}

National Cancer Institute. Competent Authority Applicant. NCI Thesaurus. Code C127522.

The person responsible for the competent authority application. 